\title{
The effectiveness of schistosomiasis health education session in primary and secondary schools in Pemba Island, Zanzibar
}

Da Cheng Xu

Jintan CDC

Wei Li

Jiangsu Institute of Parasitic Diseases

Saleh Juma

Ministry of Health of Zanzibar

Ming Zhen He

Changzhou CDC

Fatma Kabole

Ministry of Health of Zanzibar

Xin Yao Wang

Jiangsu Institute of Parasitic Diseases

Kun Yang ( $\sim$ jipdyk@163.com )

Jiangsu Institute of Parasitic Diseases https://orcid.org/0000-0002-0898-0600

\section{Research article}

Keywords: effectiveness, Schistosomiasis, Health education sessions, Zanzibar

Posted Date: October 23rd, 2019

DOI: https://doi.org/10.21203/rs.2.13577/v2

License: () (i) This work is licensed under a Creative Commons Attribution 4.0 International License. Read Full License 


\section{Abstract}

Background: Schistosomiasis seriously endangers the health of African people, hinders local economic and social development, and becomes a serious local public health problem. However, in addition to preventive chemotherapy, other social, environmental and health promotion measures are progressing slowly, lack of sanitation, treated water, and systematic health education, the people are still at risk of infection. In 2011, a survey of 24 school in Zanzibar showed that the average infection rate of Schistosoma haematobium was $8 \%(0-38 \%)$ in Unguja, and was 15\% (1-43\%) in Pemba. Methods: According to the shape of the island, the island is divided into three regions: the south, the middle, and the north. A Shehia in the southern, central and northern parts of Pemba Island was randomly selected respectively, the schistosomiasis health education session was conducted in primary and secondary schools of the selected Shehias. The students were randomly selected for schistosomiasis cognitive level test by designed questionnaire including 8 knowledge questions and 4 behavior questions before and after health education, through a chi-square test of the awareness rate and the correct behavior rate of schistosomiasis before and after the health education, the effect of health education session was evaluated. Result: A total 712 students were sampled before and after the health education in 8 schools. Before the health education session, the awareness rates of schistosomiasis were $64.62 \%$ and $68.75 \%$ among primary and secondary school respectively. After the session, the awareness rates increased to $79.74 \%$ and $84.70 \%$ respectively, and the difference was statistically significant $(\chi 2=179.3, P<0.0001)$. Before the sessions, the correct behavior rates were $63.96 \%$ and $54.79 \%$ among boys and girls. After the sessions, the correct behavior rates increased to $82.83 \%$ and $76.58 \%$, and the difference was also statistically significant $(X 2=143.8, P<0.0001)$. Conclusion: The awareness rate and correct behavior rate of schistosomiasis were low in Pemba Island, Zanzibar, hence the schistosomiasis health education needs to be strengthened. The schistosomiasis health education session has an obvious effect on the improvement of cognitive level of schistosomiasis among local students. This method can be promoted and implemented in local schools with the effort of local health and education departments.

\section{Background}

As a neglected tropical disease, Schistosomiasis is endemic in 76 countries and regions in the tropics and subtropics[1, 2]. It is estimated that 200 million people are infected every year and another 800 million people are at risk of infection. Sub-Saharan Africa (SSA) accounts for more than $90 \%$ of cases [3, 4]. Schistosomiasis seriously endangers the health of African people, hinders local economic and social development, and becomes a serious local public health problem.

Zanzibar is a part of Tanzania and is located on the east coast of Africa, with two main islands of Unguja and Pemba. Zanzibar is historically a heavily endemic area for Schistosomiasis haematobium. Since 1994, the Zanzibar government has implemented preventive chemotherapy measure, and the infection rate of the population has been declining $[5,6]$. However, in addition to preventive chemotherapy, other social, environmental and health promotion measures are progressing slowly, lack of sanitation, treated water, and systematic health education, the local people are still at risk of infection. According to a survey of 24 school in 2011 in Zanzibar, the average infection rate of S. haematobium in school was 8\% (0-38\%) in Unguja, and was 15\% (1-43\%) in Pemba [7].

There are many prevention and control measures for schistosomiasis, including preventive chemotherapy, snail control, environmental and facility improvement, health education, etc[8-12]. Among these prevention and treatment measures, health education has less investment and good social benefits[13, 14]. It has a high input-output ratio and is an economic and effective prevention and control method. It is also a basic schistosomiasis control strategy in many endemic countries[15]. In China, health education is highly valued in schistosomiasis prevention and control. Governments at all levels have adopted and implemented a variety of health education models such as school health education session, snail activity and essay competition, and have achieved good results. These have been widely recognized and praised by the international community and have a wide impact[16-18].

At present, the prevention and control measures of schistosomiasis in Zanzibar are still based on preventive chemotherapy, other related measures are less implemented. Some organizations or institutions carried out KAP survey in local area[19], or tried some health education measures for research, but the effect was not good [20]. The schistosomiasis health education has not been effectively implemented in schools and communities.

The Zanzibar population structure is mainly based on adolescents[21], through health education for them, they can quickly improve their schistosomiasis cognition and spread relevant knowledge to their peers and family members $邓$ this will improve the cognition of

Page 2/11 
the entire population and have a good blocking effect on disease transmission[19, 22].

The school is a concentrated place for young people, conducting schistosomiasis health education session for students in school, it is easy to implement, low-cost and easy to evaluate. Through the pre- and post-health education tests, the effect of schistosomiasis health education session, its feasibility and limitation were evaluated

\section{Methods}

\section{Location and population}

According to the shape of the island, the island is divided into three regions: the south, the middle, and the north., the Shehias named Mtangani (southern), Kiuyu (central), and Wingwi (northern) were randomly selected in three regions respectively, they covered 5 primary and 3 secondary schools. All students in the 8 selected schools participated in schistosomiasis health education session. Primary schools consist of grades 1-6, and secondary schools consist of grades 1-3. The detail location of three selected Shehias is in Figure 1.

\section{Health education sessions}

Different from other forms of health education in the form of games, this schistosomiasis health education session is similar to traditional health education class, but rich in content and form. Compared to the simple knowledge in the textbook, the session's content is more systematic, it includes the lifecycle of S.haematobia, the transfer vector, the way of infection, prevention and treatment, and other knowledge of schistosomiasis, also the form is rich, it combines video broadcasting, Sample display(Bulinus and other snails), case explanation, questioning and answering and so on. All of this is to enrich the live teaching mode and create an interactive learning atmosphere.

Before the health education, the NTD staffs contacted the selected school firstly. The school teacher organized, coordinated, and arranged the time and place of the health education session. Before the session, the NTD staffs consented to every student and told them that some of them would accept schistosomiasis cognitive level test before and after the health education. The number of students for session was kept within 100 people.. The session time is within one hour. The lectures were carried out by the local NTD staff in Swahili. Before each session, 10 students were randomly selected for schistosomiasis cognitive level test. The selected students included grades 3-6 in primary school and grades 1-3 in secondary school. Due to the limited academic qualification and unable to complete the test independently, the students of grades 1-2 in primary school were excluded. The same cognitive level test was conducted again one week later, according to the sampling situation of pre-test, the same number samplers were matched as consistent as before possibly. Through the comparison of effect indicators before and after the education, the effect of health education session was evaluated.

The indicators of effectiveness evaluation in questionnaire include the awareness rate and the correct behavior rate of schistosomiasis. The awareness rate refers to the degree of understanding of schistosomiasis in the surveyed subjects, it consists of 8 knowledge questions, mainly including the knowledge about the symptoms of schistosomiasis, the way of infection, the transfer vector, etc. The calculation formula is the correct knowledge of schistosomiasis/the total knowledge of schistosomiasis ${ }^{\star} 100 \%$; the correct behavior rate refers to the proportion of correct behavior of schistosomiasis in the survey subjects, it consists of 4 behavior questions, mainly including the behaviors about prevention and treatment The calculation formula is the number of correct behaviors of schistosomiasis/the total number of behaviors of schistosomiasis * $100 \%$.

\section{Statistical Analysis}

Using EpiData3.1 to establish a database, students' test paper was double-entered and consistency tested, using SPSS19.0 statistical software for data collation and statistical analysis. The rate was compared using a chi-square test, $\mathrm{P}<0.05$ was considered statistically significant.

\section{Results}

\section{Population samples before and after health sessions}


From May to July, there were 19 sessions and 18 sessions were conducted in primary school and secondary school respectively. In the pre-test, a total of 356 valid questionnaires were obtained in post-test, we matched the same number of student possibly in posttest, and the total valid questionnaires is 712 . The sampled students were grades 3-6 in primary schools and grades 1-3 in secondary schools. All the levels of the students use the same questionnaire. There were 163 male students (45.79\%) and 193 female students (54.21\%) in pre-test, 182 male students $(51.12 \%)$ and 174 female students $(48.88 \%)$ in post-test. The average age was 14.65 and 14.83 years in pre- and post-tests respectively. The statistical results of knowledge and behavior of schistosomiasis in pre- and post-tests are shown in table 1.

Table 1 The statistical results of knowledge and behavior of schistosomiasis in pre- and post-tests in Pemba island, Zanzibar

\begin{tabular}{|c|c|c|c|}
\hline No & Contents & Before health education $\square \mathrm{n}=356 \square$ & After health education $\square n=356$ ) \\
\hline \multirow[t]{3}{*}{1} & Do you know schistosomiasis? & & \\
\hline & Yes & $204(57.30 \%)$ & $309(86.80 \%)$ \\
\hline & No & $144(40.45 \%)$ & $46(12.92)$ \\
\hline \multirow[t]{5}{*}{2} & What disease is schistosomiasis? & & \\
\hline & Respiratory disease & $10(2.81 \%)$ & $5(1.40 \%)$ \\
\hline & Mental disease & $60(16.85 \%)$ & $52(14.61 \%)$ \\
\hline & Intestinal infection & $21(5.90 \%)$ & $39(10.96 \%)$ \\
\hline & Parasitic disease & $260(73.03 \%)$ & $260(73.03 \%)$ \\
\hline \multirow[t]{5}{*}{3} & What species cause $S$. haematobium? & & \\
\hline & Vescular blood flukes & $196(55.06 \%)$ & $280(78.65 \%)$ \\
\hline & Intestinal worms & $44(12.36 \%)$ & $21(5.90 \%)$ \\
\hline & Leechs worms & $71(19.94 \%)$ & $38(10.67 \%)$ \\
\hline & Mosquito parasites & $41(11.52 \%)$ & $15(4.21 \%)$ \\
\hline \multirow[t]{4}{*}{4} & $\begin{array}{l}\text { What's the intermediate host of S. haematobium in Zanzibar? } \\
\text { Fly }\end{array}$ & $42(11.80 \%)$ & $10(2.81 \%)$ \\
\hline & Snail & $265(74.44 \%)$ & $335(94.10 \%)$ \\
\hline & Mosquito & $24(6.74 \%)$ & $6(1.69 \%)$ \\
\hline & Mended & $22(6.18 \%)$ & $5(1.40 \%)$ \\
\hline \multirow[t]{5}{*}{5} & Which of the following pictures is Bulinus globosus? & & \\
\hline & & $17(4.78 \%)$ & $15(4.21 \%)$ \\
\hline & & $109(30.62 \%)$ & $195(54.78 \%)$ \\
\hline & & $114(32.02 \%)$ & $55(15.45 \%)$ \\
\hline & & $110(30.90 \%)$ & $90(25.28 \%)$ \\
\hline \multirow[t]{4}{*}{6} & Where does the Bulinus globosus live in? & & \\
\hline & Sea & $15(4.21 \%)$ & $10(2.81 \%)$ \\
\hline & Land & $29(8.15 \%)$ & $16(4.49 \%)$ \\
\hline & Pond or stream & $293(82.30 \%)$ & $323(90.73 \%)$ \\
\hline \multirow[t]{4}{*}{7} & What's the way that schistosomiasis enters the human body? & & \\
\hline & Nose & $28(7.87 \%)$ & $11(3.09 \%)$ \\
\hline & Mouth & $41(11.52 \%)$ & $16(4.49 \%)$ \\
\hline & Skin & $273(76.69 \%)$ & $327(91.85 \%)$ \\
\hline \multirow[t]{5}{*}{8} & What are the main symptom of S. haematobium infection? & & \\
\hline & High blood pressure (Hypertension) & $27(7.58 \%)$ & $16(4.49 \%)$ \\
\hline & Fever & $17(4.78 \%)$ & $12(3.37 \%)$ \\
\hline & Hematuresis & $298(83.71 \%)$ & $311(87.36 \%)$ \\
\hline & Dizzy & $8(2.25 \%)$ & $17(4.78 \%)$ \\
\hline \multirow[t]{5}{*}{9} & What's the way to prevent schistosomiasis? & & \\
\hline & Do not touch the contaminated water & $208(58.43 \%)$ & $291(81.74 \%)$ \\
\hline & Vaccination & $54(15.17 \%)$ & $28(7.87 \%)$ \\
\hline & Wash hands before meal or after pee & $48(13.48 \%)$ & $21(5.90 \%)$ \\
\hline & Don't touch the infected patient & $40(11.24 \%)$ & $12(3.37 \%)$ \\
\hline \multirow[t]{3}{*}{10} & Can schistosomiasis patient be infected again after treatment? & & \\
\hline & Yes & $182(51.12 \%)$ & $231(64.89 \%)$ \\
\hline & No & $154(43.26 \%)$ & $117(32.87 \%)$ \\
\hline \multirow[t]{3}{*}{11} & Do you think schistosomiasis can be treated? & & \\
\hline & Yes & $278(78.09 \%)$ & $297(83.43 \%)$ \\
\hline & 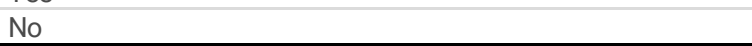 & $61(17.13 \%)$ & $44(12.36 \%)$ \\
\hline \multirow[t]{3}{*}{12} & Do you pee in ponds or streams? & & \\
\hline & Yes & $123(34.55 \%)$ & $32(8.99 \%)$ \\
\hline & No & $172(48.31 \%)$ & $317(89.04 \%)$ \\
\hline
\end{tabular}

Note: There are missing answers, so the total is not necessarily 356 


\section{The awareness rate and correct behavior rate before health education session.}

Table 2 shows that the awareness rates of schistosomiasis among primary school and secondary school were $64.62 \%$ and $68.75 \%$ respectively, and the correct behavior rate were $58.24 \%$ and $59.77 \%$ respectively. The awareness rates of schistosomiasis among male and female was $65.64 \%$ and $67.49 \%$, and the correct behavior rate was $63.96 \%$ and $54.79 \%$. The difference of awareness rate among primary school and secondary school was statistically significant $\left(X^{2}=5.2520, P=0.0219\right)$, also the difference of correct behavior rate between male and female was statistically significant $\left(\chi^{2}=11.895, P=0.0006\right)$.

Table 2 The detail of students' awareness rate and correct behavior rate of $S$. haematobium before health education in Pemba

\begin{tabular}{|c|c|c|c|c|c|c|c|}
\hline \multirow[t]{2}{*}{ Classification } & \multirow[t]{2}{*}{ Content } & \multicolumn{2}{|c|}{ School } & \multirow{2}{*}{$\begin{array}{c}\text { Chi- } \\
\text { square } \\
\text { test }\end{array}$} & \multirow{2}{*}{$\begin{array}{c}P \\
\text { value }\end{array}$} & \multicolumn{2}{|c|}{ Gender } \\
\hline & & $\begin{array}{c}\text { Primary } \\
\text { school } \\
(n=182\end{array}$ & $\begin{array}{c}\text { Secondary } \\
\text { school } \quad(n=174)\end{array}$ & & & $\begin{array}{l}\text { Male } \\
(n=163)\end{array}$ & $\begin{array}{l}\text { Female } \\
(n=193)\end{array}$ \\
\hline \multirow{8}{*}{$\begin{array}{l}\text { The awareness } \\
\text { rate }\end{array}$} & Do you know schistosomiasis? & $73(40.11 \%)$ & $131(75.29 \%)$ & \multirow[t]{8}{*}{5.2520} & \multirow[t]{8}{*}{0.0219} & $98(60.12 \%)$ & $106(54.92 \%)$ \\
\hline & What disease is schistosomiasis? & $125(68.68 \%)$ & $135(77.59 \%)$ & & & $114(69.94 \%)$ & $146(75.65 \%)$ \\
\hline & $\begin{array}{l}\text { What species cause S. } \\
\text { haematobium? }\end{array}$ & $106(58.24 \%)$ & $90(51.72 \%)$ & & & $83(50.92 \%)$ & $113(58.55 \%)$ \\
\hline & $\begin{array}{l}\text { What's the intermediate host of } \\
\text { S.haematobium in Zanzibar? }\end{array}$ & $136(74.73 \%)$ & $129(74.14 \%)$ & & & $125(76.69 \%)$ & $140(72.54 \%)$ \\
\hline & $\begin{array}{l}\text { Which of the following pictures is } \\
\text { Bulinus globosus? }\end{array}$ & $62(34.07 \%)$ & $47(27.01 \%)$ & & & $43(26.38 \%)$ & $66(34.20 \%)$ \\
\hline & $\begin{array}{l}\text { Where does the Bulinus globosus live } \\
\text { in? }\end{array}$ & $146(80.22 \%)$ & $147(84.48 \%)$ & & & $137(84.05 \%$ & $156(80.83 \%)$ \\
\hline & $\begin{array}{l}\text { What's the way that schistosomiasis } \\
\text { enters the human body? }\end{array}$ & $144(79.12 \%)$ & $129(74.14 \%)$ & & & $124(76.07 \%)$ & $149(77.20 \%)$ \\
\hline & $\begin{array}{l}\text { What are the main symptom of S. } \\
\text { haematobium infection? }\end{array}$ & $149(81.87 \%)$ & $149(85.63 \%)$ & & & $132(80.98 \%)$ & 166(86.01\%) \\
\hline \multirow[t]{4}{*}{$\begin{array}{l}\text { The correct } \\
\text { behavior rate }\end{array}$} & $\begin{array}{l}\text { What's the way to prevent } \\
\text { schistosomiasis? }\end{array}$ & $103(56.59 \%)$ & $105(60.34 \%)$ & \multirow[t]{4}{*}{0.2830} & \multirow[t]{4}{*}{0.5946} & $100(61.35 \%)$ & $108(55.96 \%)$ \\
\hline & $\begin{array}{l}\text { Can schistosomiasis patient be } \\
\text { infected again after treatment? }\end{array}$ & $97(53.30 \%)$ & $85(48.85 \%)$ & & & $97(59.51 \%)$ & $85(44.04 \%)$ \\
\hline & $\begin{array}{l}\text { Do you think schistosomiasis can be } \\
\text { cured? }\end{array}$ & $138(75.82 \%)$ & $140(80.46 \%)$ & & & $137(84.05 \%)$ & $141(73.06 \%)$ \\
\hline & Do you pee in ponds or streams? & $86(47.25 \%)$ & $86(49.43 \%)$ & & & $83(50.92 \%)$ & $89(46.11 \%)$ \\
\hline
\end{tabular}

\section{The awareness rate and correct behavior rate after health education.}

Between primary school and secondary school, the awareness rate of schistosomiasis was $79.74 \%$ and $84.70 \%$ respectively, with the statistically significant difference $(\chi 2=11.607, P=0.0007)$, and the correct behavior rate was $78.30 \%$ and $81.32 \%$ respectively. Between male and female students, the awareness rates of schistosomiasis among male and female were $82.69 \%$ and $81.61 \%$ respectively, and the correct behavior rate was $82.83 \%$ and76.58\% respectively, with the statistically significant difference $(\chi 2=8.23$, $\mathrm{P}=0.0041$ ). The details are shown in Table 3 . 
Table 3 The detail of students' awareness rate and correct behavior rate of $S$. haematobium after health education in Pemba island, Zanzibar

\begin{tabular}{|c|c|c|c|c|c|c|c|}
\hline \multirow[t]{2}{*}{ Classification } & \multirow[t]{2}{*}{ Content } & \multicolumn{2}{|c|}{ School } & \multirow{2}{*}{$\begin{array}{c}\text { Chi- } \\
\text { square } \\
\text { test }\end{array}$} & \multirow{2}{*}{$\begin{array}{c}\mathrm{P} \\
\text { value }\end{array}$} & \multicolumn{2}{|c|}{ Gender } \\
\hline & & $\begin{array}{l}\text { Primary } \\
\text { school } \\
(n=182)\end{array}$ & $\begin{array}{l}\text { Secondary } \\
\text { school } \\
(n=174)\end{array}$ & & & $\begin{array}{l}\text { Male } \\
\quad(n=182)\end{array}$ & $\begin{array}{l}\text { Female } \\
\qquad(n=174)\end{array}$ \\
\hline \multirow{8}{*}{$\begin{array}{c}\text { The } \\
\text { awareness } \\
\text { rate }\end{array}$} & Do you know schistosomiasis? & $144(79.12 \%)$ & 165(94.83\%) & \multirow[t]{8}{*}{11.607} & \multirow[t]{8}{*}{0.0007} & 164(90.11\%) & 145(83.33\%) \\
\hline & What disease is schistosomiasis? & 134(73.63\%) & $126(72.41 \%)$ & & & 131(71.98\%) & $129(74.14 \%)$ \\
\hline & $\begin{array}{l}\text { What species cause } \mathrm{S} \text {. } \\
\text { haematobium? }\end{array}$ & $132(72.53 \%)$ & $148(85.06 \%)$ & & & $139(76.37 \%)$ & $141(81.03 \%)$ \\
\hline & $\begin{array}{l}\text { What's the intermediate host of } \\
\text { S.haematobium in Zanzibar? }\end{array}$ & 168(92.31\%) & 167(95.98\%) & & & $169(92.86 \%)$ & $166(95.40 \%)$ \\
\hline & $\begin{array}{l}\text { Which of the following pictures is } \\
\text { Bulinus globosus? }\end{array}$ & $93(51.10 \%)$ & $102(58.62 \%)$ & & & $110(60.44 \%)$ & $85(48.85 \%)$ \\
\hline & $\begin{array}{l}\text { Where does the Bulinus globosus } \\
\text { live in? }\end{array}$ & 162(89.01\%) & 161(92.53\%) & & & 162(89.01\%) & $161(92.53 \%)$ \\
\hline & $\begin{array}{l}\text { What's the way that } \\
\text { schistosomiasis enters the human } \\
\text { body? }\end{array}$ & $169(92.86 \%)$ & 158(90.80\%) & & & 166(91.21\%) & $161(92.53 \%)$ \\
\hline & $\begin{array}{l}\text { What are the main symptom of S. } \\
\text { haematobium infection? }\end{array}$ & $159(87.36 \%)$ & 152(87.36\%) & & & $163(89.56 \%)$ & $148(85.06 \%)$ \\
\hline \multirow[t]{4}{*}{$\begin{array}{l}\text { The correct } \\
\text { behavior rate }\end{array}$} & $\begin{array}{l}\text { What's the way to prevent } \\
\text { schistosomiasis? }\end{array}$ & 147(80.77\%) & $144(82.76 \%)$ & \multirow[t]{4}{*}{1.835} & \multirow[t]{4}{*}{0.1755} & 154(84.62\%) & $137(78.74 \%)$ \\
\hline & $\begin{array}{l}\text { Can schistosomiasis patient be } \\
\text { infected again after treatment? }\end{array}$ & $119(65.38 \%)$ & $112(64.37 \%)$ & & & $125(68.68 \%)$ & $106(60.92 \%)$ \\
\hline & $\begin{array}{l}\text { Do you think schistosomiasis can } \\
\text { be cured? }\end{array}$ & $150(82.42 \%)$ & 147(84.48\%) & & & 161(88.46\%) & $136(78.16 \%)$ \\
\hline & Do you pee in ponds or streams? & $154(84.62 \%)$ & 163(93.68\%) & & & $163(89.56 \%)$ & 154(88.51\%) \\
\hline
\end{tabular}

\section{Comparison of the awareness rate and correct behavior rate before and after session.}

The awareness rates of schistosomiasis among all students were significant increasing from $66.64 \%$ to $82.16 \%$ after health education $\left(\chi^{2}=179.279, p<0.0001\right)$. The correct behavior rates were also significant increasing from $58.99 \%$ to $79.78 \%\left(X^{2}=143.84\right.$, $\mathrm{P}<0.0001) \otimes$ Table $4 \rrbracket$.

For primary school, the awareness rates were significant increasing from $64.63 \%$ to $79.74 \%\left(\chi^{2}=82.0284, P<0.0001\right)$. The correct behavior rates were significant increasing from $58.24 \%$ to $78.30 \%\left(\chi^{2}=66.66, P<0.0001\right)$. For secondary school, the awareness rate was significant increasing from $68.75 \%$ to $84.70 \%\left(\chi^{2}=98.238, P<0.0001\right)$, and the correct behavior rates were also significant increasing from $59.77 \%$ to $81.32 \%(566 / 696)\left(\chi^{2}=76.757, P<0.0001\right)$.

For boy student $囚$ the awareness rates were significant increasing from $65.64 \%$ to $82.69 \%\left(\chi^{2}=110.652, P<0.0001\right)$. and the correct behavior rates were also significant increasing from $63.96 \%$ to $82.83 \%\left(\chi^{2}=62.561, P<0.0001\right)$. For girl student, the awareness rates were significant increasing from $67.49 \%$ to $81.61 \%\left(\chi^{2}=75.493, P<0.0001\right)$; the correct behavior rates were significant increasing from $54.79 \%$ to $76.58 \%\left(X^{2}=75.541, P<0.0001\right)$.

Table 4 The total students' awareness rate and correct behavior rate of $S$. haematobium before and after health education in Pemba island, Zanzibar

\begin{tabular}{|c|c|c|c|c|c|c|c|c|c|c|c|c|c|c|c|}
\hline \multirow[t]{2}{*}{ Classification } & \multicolumn{3}{|c|}{ All } & \multicolumn{3}{|c|}{ Primary school } & \multicolumn{3}{|c|}{ Secondary school } & \multicolumn{3}{|c|}{ Male } & \multicolumn{3}{|c|}{ Female } \\
\hline & Before $\llbracket n=356$ ) & After $n=356)$ & $\begin{array}{l}\text { Chi- } \\
\text { square } \\
\text { test }\end{array}$ & $\begin{array}{l}\text { Before } \\
(n=182)\end{array}$ & $\begin{array}{c}\text { After } \\
(n=182)\end{array}$ & $\begin{array}{l}\text { Chi- } \\
\text { square } \\
\text { test }\end{array}$ & $\begin{array}{c}\text { Before } \\
(n=174)\end{array}$ & $\begin{array}{c}\text { After } \\
(n=174)\end{array}$ & $\begin{array}{c}\text { Chi- } \\
\text { square } \\
\text { test }\end{array}$ & $\begin{array}{c}\text { Before } \\
(n=163)\end{array}$ & $\begin{array}{c}\text { After } \\
(n=182)\end{array}$ & $\begin{array}{l}\text { Chi- } \\
\text { square } \\
\text { test }\end{array}$ & $\begin{array}{c}\text { Before } \\
(n=193)\end{array}$ & $\begin{array}{c}\text { After } \\
(n=174)\end{array}$ & $\begin{array}{c}\text { Chi- } \\
\text { square } \\
\text { test }\end{array}$ \\
\hline $\begin{array}{c}\text { The } \\
\text { awareness } \\
\text { rate }\end{array}$ & $1898 / 2848$ & $2340 / 2848$ & 179.3 & $941 / 1456$ & $1161 / 1456$ & 682.028 & $957 / 1392$ & 1179/1392 & 298.238 & $856 / 1304$ & $1204 / 1456$ & 110.652 & 1042/1544 & $1136 / 1392$ & 275.493 \\
\hline $\begin{array}{c}\text { The correct } \\
\text { behavior rate }\end{array}$ & $840 / 1424$ & $1136 / 1424$ & 143.8 & $424 / 728$ & $570 / 728$ & 66.66 & $416 / 696$ & $566 / 696$ & 76.757 & $417 / 652$ & $603 / 728$ & 62.561 & $423 / 772$ & $533 / 696$ & 75.541 \\
\hline
\end{tabular}




\section{Discussion}

According to the KAP theory, knowledge is the foundation, which affects people's beliefs and behaviors and is an important factor in the infection and transmission of schistosomiasis[23]. The behavioral change requires knowledge-based and takes time to form.() The study showed that the schistosomiasis cognitive level among local students is still very low, which is similar to or even lower than previous studies in Tanzania, Cameroon, Senegal, Kenya and other countries. [24-27].

In African countries, students have a higher rate of schistosomiasis infection [28], as well as in Zanzibar [29]. In addition to preventive chemotherapy, other social, environmental and health interventions for schistosomiasis control in Zanzibar are implemented slowly now, if the schistosomiasis health education is not popularized, it is difficult to achieve the elimination level of schistosomiasis control in local area.

Through the implementation of schistosomiasis health education session, the cognition level of schistosomiasis among primary and secondary school students was significantly improved, and the effect on primary and secondary school students was quite. This suggested that This interactive mode health education has a positive effect on the improvement of students' schistosomiasis cognitive level, the same results were obtained in some similar researches conducted in Brazil and Nigeria[30, 31]. On the contrary, some non-interactive health education modes are not effective[20].

Meanwhile, compared with the symptoms, treatment, transmission and other indicators, students' understanding of the transfer vector of S. haematobium seems weak, the awareness rate in pre-test was only $30.62 \%$, and was $54.78 \%$ in post-test. Although the improvement was great, but the effect was not as high as other indicators. The similar situation exists in aspect of reinfection. This reminds us that in the process of health education, some interactive practical activities (snail survey) should be conducted, This may deepen their impression and have a better effect.

Due to the lack of corresponding health education materials in local area (the students' natural textbook only has a brief introduction of schistosomiasis, such as symptoms and treatment), the professional quality of the teacher is not comprehensive, so the schistosomiasis health education session was mainly implemented by local NTD staffs. This study is only a short-term effect observation. Health education is a long process. In the following promotion, teachers will definitely be trained and the health education will be implemented by them as the main force.

If this model is promoted and popularized, it requires the effort of the whole society, in particular, the health and education departments need do a lot of work: First, Zanzibar health department should provide professional training for the local teachers with the education department, and they can master the knowledge of schistosomiasis. Second, schools should set up special health education classes, teaching the knowledge of schistosomiasis with full-time or part-time teachers, and strengthen assessment. Third, the health department can conduct related essay competitions, snail-survey activities and other activities every year in schools, so that to deepen students' understanding of schistosomiasis. Fourth, the health department should develop more publicity materials and products, through which these knowledges of schistosomiasis prevention and control will reach thousands of families. Fifth, Students' health education should be constantly carried out and persevered, and the students' cognitive level should be improved through long-term indoctrination.

It is emphasized that, schistosomiasis control is an integrated strategy, health education plays an important role in promoting and maintaining and schistosomiasis control [32]. However, health education must be implemented with social, environmental and health interventions (sanitation and clean water) in areas that are endemic for schistosomiasis. Without these measures support, people will continue to use potentially contaminated water sources, the control effect will be greatly reduced[33].

In addition, this study has a certain limitation. For example, the health education session was conducted for all students in selected schools, but the local students' absenteeism rate was very high (up to $20 \%$, according to the observation and the teacher's statement). If the study evaluates the effect by the same people before and after the health education, the data may be missing too much and this will impact the analysis. Therefore, we matched the same number samples according to the sampling situation in pretest, and kept the samples as consistent as possible. Another issue is the evaluation time of post-test is too short. As time goes by, the actual result may be lower than the result of the assessment, this also indicates that health education needs continuity and longterm. 


\section{Conclusion}

The KAP model is a behavioral intervention theory, which divides human behavior changes into three successive stages: acquiring knowledge, generating beliefs and forming behaviors. Therefore, it takes a certain time to form an effect. Acquiring knowledge is the foundation, and health education is one of the effective ways. Children are ideal candidates because of their plasticity and high acceptability. At present, the schistosomiasis cognitive level in students in Pemba, Zanzibar is low. Through the implementation of schistosomiasis health education session, the cognitive level of students has been significantly improved. Therefore, this method can be recommended to be promoted throughout Zanzibar.

\section{Abbreviations}

S. haematobium: Schistosoma haematobium; KAP: Knowledge- Attitude-Practice; Shehia: Zanzibar Administrative Village Unit; NTD: Neglected Tropical Disease; SPSS: Statistical Package for the Social Sciences

\section{Declarations}

\section{Acknowledgements}

We thank the schools and pupils that participated. We also thank the staff of Zanzibar NTD office for their on-site coordination and support.

\section{Funding}

This work was funded by the Ministry of Commerce of the People's Republic of China (No. 2015400302209101); this project was supported by Jiangsu Commission of Health (ZDRC2016056). The funding body did not participate in the design of the study; collection, analysis, and interpretation of data; and in writing the manuscript.

\section{Availability of data and materials}

The transcripts used and analysed during the current study are available from the corresponding author on reasonable request.

\section{Authors' contributions}

DCX planned, designed the study, facilitated the fieldwork, collected the data, and wrote the manuscript. WL planned, designed the study, prepared schistosomiasis health education sessions, and contributed significantly to the writing of the manuscript. SJ planned, designed the study, and facilitated the fieldwork. MZH designed the test form, facilitated the fieldwork, collected the data. FK planned, designed the study, and facilitated the fieldwork. XYW facilitated the fieldwork, collected and analysed the data. KY planned, designed the study, and contributed significantly to the writing of the manuscript. All authors read and approved the final manuscript.

\section{Ethics approval and consent to participate}

The field studies did not involve endangered or protected species. All subject enrollment has been signed the informed consent of this study. For all participants who were not adult, a parent or guardian provided informed consent on their behalf. The study was approved by the local government of Pemba Island. In addition, the Ethics Review Committee of Zanzibar approved all studies described here (ZAMREC/002/MAY/014). Four main principles in research ethics were applied in this study; to cause no harm to the participants, to obtain informed consent, to protect participants, and not to deceive the participants. 


\section{Consent for publication}

All participants signed individual consent forms with consent to publish.

\section{Competing interests}

The authors declare that they have no competing interests.

\section{Author details}

1 National Health Commission Key Laboratory of Parasitic Disease Control and Prevention, Jiangsu Provincial Key Laboratory on Parasite and Vector Control Technology, Jiangsu Institute of Parasitic Diseases, Wuxi, Jiangsu Province, 214064, China;

2 Center for Disease Control and Prevention of Jintan District, Changzhou, Jiangsu 213200, China;

3 Ministry of Health of Zanzibar, P.O. Box 236, Zanzibar, United Republic of Tanzania;

4 Center for Disease Control and Prevention of Changzhou City, Changzhou, Jiangsu 213022, China.

\section{References}

1. Engels, D., et al., The Global Epidemiological Situation of Schistosomiasis and New Approaches to Control and Research. Acta tropica, 2002. 82(2): p. 139-146.

2. Engels, D. and L. Savioli, Pubic Health Strategies for Schistosomiasis Control, in Schistosomiasis. 2005, Springer. p. $207-222$.

3. Noriode, R.M., et al., Urinary schistosomiasis in school aged children of two rural endemic communities in Edo State, Nigeria. Journal of infection and public health, 2018. 11(3): p. 384-388.

4. Fenwick, A., Schistosomiasis: number of people treated worldwide in 2014. 2016.

5. Mgeni, A., et al., Metrifonate in the control of urinary schistosomiasis in Zanzibar. Bulletin of the World Health Organization, 1990. 68(6): p. 721.

6. Stothard, J.R., et al., The epidemiology and control of urinary schistosomiasis and soil-transmitted helminthiasis in schoolchildren on Unguja Island, Zanzibar. Transactions of the Royal Society of Tropical Medicine and Hygiene, 2009. 103(10): p. 1031-1044.

7. Knopp, S., et al., Study and implementation of urogenital schistosomiasis elimination in Zanzibar (Unguja and Pemba islands) using an integrated multidisciplinary approach. BMC Public Health, 2012. 12(1): p. 930.

8. Chitsulo, L., et al., The global status of schistosomiasis and its control. Acta tropica, 2000. 77(1): p. 41-51.

9. Chimbari, M.J., Enhancing schistosomiasis control strategy for Zimbabwe: building on past experiences. Journal of parasitology research, 2012. 2012.

10. Sokolow, S.H., et al., Global assessment of schistosomiasis control over the past century shows targeting the snail intermediate host works best. PLoS neglected tropical diseases, 2016. 10(7): p. e0004794.

11. Mazigo, H.D., et al., Epidemiology and control of human schistosomiasis in Tanzania. Parasites \& vectors, 2012. 5(1): p. 274.

12. Hürlimann, E., et al., Effect of an integrated intervention package of preventive chemotherapy, community-led total sanitation and health education on the prevalence of helminth and intestinal protozoa infections in Côte d'Ivoire. Parasites \& vectors, 2018. 11(1): p. 115.

13. Liu, G., et al., PRD4: COST BENEFIT ANALYSIS OF ASTHMA EDUCATION PROGRAMS. Value in Health, 1999. 2(3): p. 178-179.

14. Wylie, W.E., Cost-benefit analysis of a school health education program: one method. Journal of School Health, 2010. 53(6): p. 371-373. 
15. Asaolu, S. and I. Ofoezie, The role of health education and sanitation in the control of helminth infections. Acta tropica, 2003. 86(2-3): p. 283-294.

16. Han-Bing, X., H. Chun-Mei, and S. Xiao-Wen, [Evaluation of health education of medium- and long-term planning of schistosomiasis prevention and control in Kunshan City]. Zhongguo xue xi chong bing fang zhi za zhi = Chinese journal of schistosomiasis control, 2016. 28(6): p. 732.

17. Li-Ming, J., et al., [Present situation of health education work in schistosomiasis control and evaluation on its effectiveness in Hubei Province]. Zhongguo Xue XI Chong Bing Fang Zhi Za Zhi, 2016. 29(2): p. 202-205.

18. Zheng, X., et al., Evaluation of the short-term effect of anti-Schistosomisis health education in Guichi county,Chizhou city of Anhui. Journal of Tropical Diseases \& Parasitology, 2010.

19. Person, B., et al., Community knowledge, perceptions, and practices associated with urogenital schistosomiasis among schoolaged children in Zanzibar, United Republic of Tanzania. PLoS neglected tropical diseases, 2016. 10(7): p. e0004814.

20. Stothard, J., et al., Health education and the control of urogenital schistosomiasis: assessing the impact of the Juma na Kichocho comic-strip medical booklet in Zanzibar. Journal of biosocial science, 2016. 48(S1): p. S40-S55.

21. Blacker, J.G.C., Population Growth and Differential Fertility in Zanzibar Protectorate. Population Studies.

22. Guanghan, H., et al., The role of health education for schistosomiasis control in heavy endemic area of Poyang Lake region, People's Republic of China. Southeast Asian Journal of Tropical Medicine \& Public Health, 2000. 31(3): p. 467-472.

23. Guang-Han, $\mathrm{H}$., et al., Challenges and strategies of health education and health promotion in stage of schistosomiasis elimination. Zhongguo xue xi chong bing fang zhi za zhi= Chinese journal of schistosomiasis control, 2018. 30(2): p. 117-120.

24. Folefac, L.N., et al., Knowledge, attitudes and practices regarding urinary schistosomiasis among adults in the Ekombe Bonji Health Area, Cameroon. The Pan African medical journal, 2018. 29: p. 161-161.

25. Munisi, D.Z., et al., Knowledge, attitude, and practices on intestinal schistosomiasis among primary schoolchildren in the Lake Victoria basin, Rorya District, north-western Tanzania. BMC public health, 2017. 17(1): p. 731.

26. Odhiambo, G.O., et al., Low levels of awareness despite high prevalence of schistosomiasis among communities in Nyalenda informal settlement, Kisumu City, Western Kenya. PLoS neglected tropical diseases, 2014. 8(4): p. e2784.

27. Sow, S., et al., Low awareness of intestinal schistosomiasis in northern Senegal after 7 years of health education as part of intense control and research activities. Tropical Medicine \& International Health, 2003. 8(8): p. 744-749.

28. Teshale, T., et al., Prevalence of intestinal helminths and associated factors among school children of Medebay Zana wereda; North Western Tigray, Ethiopia 2017. BMC research notes, 2018. 11(1): p. 444.

29. Knopp, S., et al., Elimination of schistosomiasis transmission in Zanzibar: baseline findings before the onset of a randomized intervention trial. PLoS neglected tropical diseases, 2013. 7(10): p. e2474.

30. Gazzinelli, M.F., et al., Improving the understanding of schistosomiasis among adolescents in endemic areas in Brazil: $A$ comparison of educational methods. Patient education and counseling, 2016. 99(10): p. 1657-1662.

31. Ejike, C.U., et al., Development and testing of Schisto and Ladders ${ }^{T M}$, an innovative health educational game for control of schistosomiasis in schoolchildren. BMC research notes, 2017. 10(1): p. 236.

32. Guo, J.G., et al., The role of 'passive chemotherapy' plus health education for schistosomiasis control in China during maintenance and consolidation phase. Acta Tropica, 2005. 96(2-3): p. 177-183.

33. Montresor, et al., Guidelines for the evaluation of soil-transmitted helminthiasis and schistosomiasis at community level: a guide for managers of control programmes. Transactions of the Royal Society of Tropical Medicine \& Hygiene, 1998. 92(4): p. 470471.

\section{Figures}




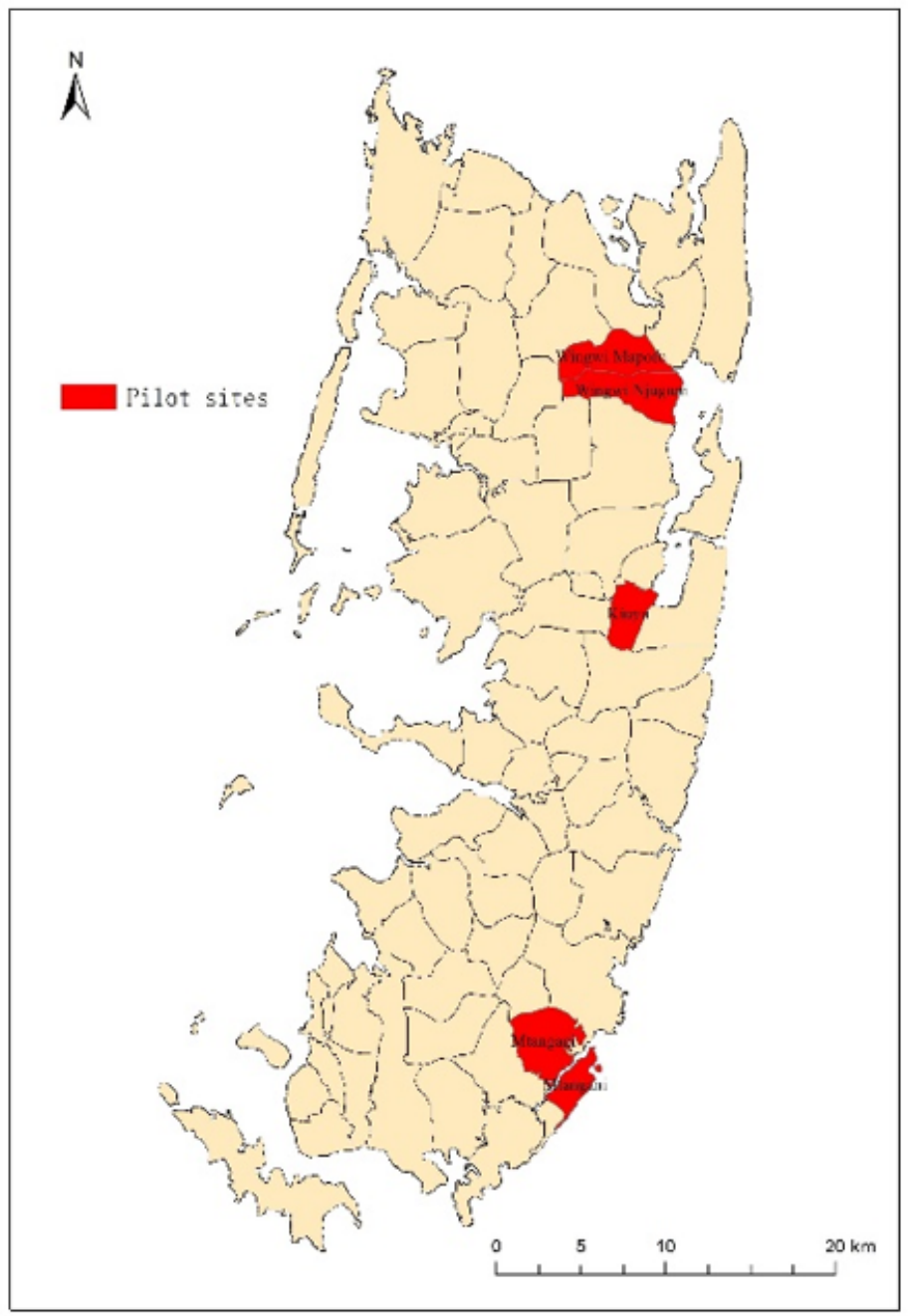

Figure 1

3 pilots in Pemba Island 